Máté Zoltán - László Éva - Szakács Attila

\title{
A közszolgáltatások marketing tevékenységének, ezen belül a vevőelégedettség vizsgálata, a természettudatos fogyasztók kialakulásának tükrében Jász-Nagykun-Szolnok megyében
}

\author{
Máté, Zoltán - László, Éva - Szakács, Attila: Research about marketing of public services \\ including customer satisfaction, considering the appearing tendency of environment conscious \\ consumers in the County of Jász-Nagykun-Szolnok
}

Our research is targeting the supplier companies operate in the County of Jász-Nagykun-Szolnok. The definitions of public service and public utility service will be described in this article. We examine how the County supplied with public utility services so we can have a bigger picture about how pleased or even unpleased are the people of the region about the services. Finally we discuss the subject matter of marketing activities of public utility service companies. Is the satisfaction of customers an evidence for the assumption that there is limited contest between the utility service companies?

Keywords: marketing, customer's satisfaction, public services

\section{ÖsSZEFOGLALó}

Kutatásunk a Jász-Nagykun-Szolnok megyében múködő szolgáltató vállalatokra irányul. Jelen írásban definiálásra kerülnek a közszolgáltatás, valamint a közüzemi szolgáltatás fogalma. Vizsgálat alá vonjuk a megye közüzemi szolgáltatásokkal való ellátottságát azzal a céllal, hogy a későbbiekben átfogó képet kapjunk a térség lakosságának szolgáltatásokkal való elégedettségéről. Végezetül foglalkozunk, azzal a kérdéssel, hogy a közüzemi szolgáltatást nyújtók, milyen jellegü marketing tevékenységet folytatnak, illetve ezen belül megvalósul-e a limitált versenyhelyzet, ami esetlegesen a vevőelégedettség megvalósulásában ölt testet.

Kulcsszavak: marketing, vevőelégedettség, közszolgáltatás

\section{BeVezetés}

Közszolgáltatás: „közcélú illetve közérdekű szolgáltatás, melyet a közösség minden tagja azo- nos feltételekkel vehet igénybe" (Illés, 2000). A közszféra által végzett tevékenységek körét statisztikai megközelítésben Pukli (2002) két csoportra bontja. Az egyik csoportba az üzemi jellegű tevékenységeket illetve szolgáltatásokat, a másikba pedig az intézményi jellegű szolgáltatásokat sorolja. Az Európai Unió tagállamaiban használatos System of National Account (SNA) metodika tartalmában hasonló elgondolások alapján értékeli a közszolgáltatásokat. A külön csoportba sorolt közüzemi szolgáltatások egy részét ma már nem az állam biztosítja, hanem a privatizáció után többnyire külföldi tulajdonban lévő szolgáltató cégek. Napjainkban a közüzemi szolgáltatások esetében - villamos áram, gáz, távfütés, víz és csatorna, kommunális hulladék szállítása, kezelése, távközlési és postai, vasúti közlekedési szolgáltatás, városi tömegközlekedés - már majdnem maradéktalanul érvényesülhetnek a piaci viszonyok. Igénybevételük sok esetben helyhez kötött, így a potenciális fogyasztó számára elérhetetlen lehet kiépített hálózat nélküli területeken. Ugyanakkor 
az intézményi közszolgáltatások humán jellegü jószágok (pl. oktatás, egészségügyi ellátás), valamilyen személyhez kötött szolgáltatási tevékenységet jelentenek és jellemzően nem piaci szolgáltatások. Postai szolgáltatások esetében az EU szabályozás meghatározza az egyetemes szolgáltatás kategóriáját, amelyet mindenki által elérhetően és diszkrimináció mentesen kell nyújtani. A teljes körű szolgáltatási kötelezettség mellett a szolgáltatások szűk körére kizárólagos jog illeti meg a kijelölt egyetemes postai szolgáltatót. A fenntartható szolgáltatások körének fokozatos szűkítése és a 2009-től várható teljes liberalizáció a közösségi postai szolgáltatások versenyének további megnyitását célozza.

A közüzemi szolgáltatások olyan alapvető szolgáltatások, amelyek legfontosabb jellemzői leírhatók a szervezet és az igénybevevő részéről (Hetesi, 2000).

\section{A KÖZÜZEMI SZOLGÁLTATÁSOK HELYE A SZOLGÁLTATÁSOK KÖRÉBEN}

A szolgáltatások rendkívül összetett csoportjában kiemelt szerepet töltenek be azok a vállalkozások, melyeknek tevékenysége a társadalom valamennyi tagjainak igényét kielégítik. $A$ közszolgáltatás a szolgáltatások azon sajátságos típusa, melynek legfőbb jellemzője a közösségi jelleg. Közszolgáltatás mindazon - az állam, a helyi önkormányzatok, vagy más szervezetek által nyújtott - szolgáltatás, amely a lakosok széles körének nyújt valamilyen ellátást. Közszolgáltatást nyújtanak a cégek abban az értelemben, hogy a szolgáltatásuk közcélú, illetőleg közérdekű, amelyet egy nagyobb közösség minden tagja megközelítőleg azonos feltételek mellett igénybe tud venni, ezért ezeknek a szolgáltatásoknak a rendelkezésre állása valamilyen mértékig közösségi megszervezést, illetve szabályozást, ellenőrzést igényel. (Illés, 2000). Mivel egy társadalomban a társadalom tagjai számára nyújtandó közfeladatokról nincsen lista, sem az EU-s, sem a magyar jogrend nem ad arra nézve kapaszkodót, hogy mit tekintsünk közfeladatnak, nem tudjuk pontosan, hogy ha- zánkban mit tekintsünk a kötelezően nyújtandó közfeladatnak, így először annak lehatárolása szükséges, hogy mit tekintsünk kutatásunk tárgyának, milyen tevékenységekre irányuljon pontosan a kutatásunk

A korábbi közszolgáltatásokra irányuló kutatások adnak némi támpontot a fogalom pontos lehatárolásához. 2011-ben Kiss Norbert vezette kutatás TAMOP által finanszírozott kutatás a versenyképesség és a közszolgáltatás kapcsolatának vizsgálata során adott módszertani támpontokat a szektor vizsgálatához. Dinya László kutatása a közszolgálati menedzsment sajátosságait kutatta 2002-ben, Báger Gusztáv és Czakó Erzsébet pedig 2010-ben a közszféra és a gazdaság versenyképessége címmel készített tanulmányt. Ezeknek a tanulmányoknak alapján gyüjtöttük össze a közszolgáltatásokra vonatkozó legfontosabb megállapításokat, csoportosításokat.

A közszféra által végzett tevékenységek körét statisztikai megközelítésben Pukli (2002) két

csoportra bontja. Az egyik csoportba az üzemi jellegű tevékenységeket illetve szolgáltatásokat, a másikba pedig az intézményi jellegú szolgáltatásokat sorolja. A közüzemi szolgáltatások lehatárolásánál ezt a megközelítést tartjuk kutatásunk szempontjából a leginkább megfoghatónak, ezért a továbbiakban a közüzemi szolgáltatások alatt a villamos áram, gáz, távfütés, víz és csatorna, kommunális hulladék szállítása, kezelése, távközlési és postai, vasúti közlekedési szolgáltatás, városi tömegközlekedés szolgáltatásokat értjük és a további kutatásainkat ezekre a szolgáltatókra irányítjuk.

\section{A KöZSZOLGÁLTATÁSOKAT CSOPORTOSÍTÁSA}

Tulajdonforma szerint:

a. állami, önkormányzati szereplők által nyújtott szolgáltatások

b. magánszereplők által nyújtott közszolgáltatások

c. vegyes modell- magán szféra és a közszféra egymás mellett nyújtja a szolgáltatást. (egészségügyi ellátás; a helyi tömegközlekedés) 
Finanszírozási forma szerint:

d. állam, önkormányzat által finanszírozott szolgáltatás (pl. rendőrség)

e. a fogyasztók, ügyfelek által finanszírozott szolgáltatás (pl. elektromos áram)

f. vegyes finanszírozás (pl. egészségügy)

Igénybevevők köre szerint:

g. „mindenki” - rendőrség, honvédség

h. „fogyasztók” / ügyfelek- oktatás

\section{KöZÜZEMI SZOLGÁLTATÁS FOGALMA}

A közüzemi szolgáltatások a tevékenységek statisztikai osztályozása szerint nem képeznek önálló nemzetgazdasági ágat. A gazdasági tevékenységek egységes ágazati osztályozási rendszere szerint, a szúken vett kommunális közszolgáltatási szaktevékenységek több nemzetgazdasági ághoz, ágazathoz, alágazathoz és szakágazathoz tartoznak. Ezért a terület elnevezése évtizedek óta vitatott a szakemberek között. A közüzemi megnevezést első alkalommal az állami vállalatokról szóló1977. évi VI. törvény VII. fejezete használja, amikor e tevékenységet ellátó vállalatokat közüzemi vállalatoknak nevezi és feladatukat a jelenlegi felfogás szerint - elég pontatlanul (közszükségletet kielégítő alapvető szolgáltatások folyamatos biztosítása.) határozza meg.

A közszolgáltatásokon belül vizsgálhatók azok a szolgáltatások, melyek vonatkozásában az állam a piaci verseny szempontjain túl további szempontokat is érvényesíteni akar a fogyasztók érdekében. Az ilyen szolgáltatást nyújtó cégeket tekinthetjük közüzemi szolgáltatóknak.

A közüzemek köre meglehetősen széles, ide tartozik többek között a vízellátási, csatornázási, fürdőszolgáltatások; az energiaszolgáltatások, személyszállítás stb. Találkozunk kommunális közszolgáltatások elnevezéssel is, mely alatt a helyi közszolgáltatásokat kell érteni. Bármilyen elnevezést is adunk a települési közösségi szolgáltatásoknak, leginkább a település önkormányzata tekintette feladatának a szervezését, az ellátás biztosítását.

A közüzemi szolgáltatók és a lakosság kapcsolata a más szolgáltatókkal való összevetésben számos sajátossággal jellemezhető.

A közüzemi szolgáltatások olyan alapvető szolgáltatások, amelyek legfontosabb jellemzői leírhatók a szervezet és az igénybevevő részéről (Hetesi, 2000).

\begin{tabular}{|l|l|}
\hline \multicolumn{1}{|c|}{ A szervezet részéről } & \multicolumn{1}{c|}{ Az igénybevevő részéről } \\
\hline kvázi" természetes monopolhelyzet & $\begin{array}{l}\text { alapvető szolgáltatások, } \\
\text { kicsi a helyettesítési lehetőség }\end{array}$ \\
\hline piaci verseny korlátozott & $\begin{array}{l}\text { tömeges igénybevétel, egyenlő- } \\
\text { ség, szabad hozzáférhetőség }\end{array}$ \\
\hline $\begin{array}{l}\text { közösségi tulajdonban és/vagy kö- } \\
\text { zösségi ellenőrzés alatt folyik }\end{array}$ & a szolgáltatás folyamatossága \\
\hline felvállaltan állandó tevékenység & rendszeres fogyasztás \\
\hline $\begin{array}{l}\text { országos, } \\
\text { illetve regionális kiterjedés }\end{array}$ & $\begin{array}{l}\text { folyamatos kapcsolat } \\
\text { a szervezettel }\end{array}$ \\
\hline folyamatos kapcsolat az igénylóvel & $\begin{array}{l}\text { a fogyasztói elégedettség csak } \\
\text { részben befolyásolja a cég } \\
\text { gazdasági mutatói }\end{array}$ \\
\hline $\begin{array}{l}\text { nagy, tőkeigényes beruházások, } \\
\text { lassú megtérülés }\end{array}$ & \\
\hline
\end{tabular}

A közüzemi szolgáltatások jellemzői:

- A szolgáltatás nyújtása közhatalmi rendelkezésen alapul és a szolgáltató szervezetet szolgáltatási, illetve a szolgáltatás nyújtását biztosító szerződéskötési kötelezettség terheli a fogyasztóval szemben.

- A közüzemi szolgáltatók közhatalmi engedélyben meghatározott körben és területen, rendszerint kizárólagos szolgáltatásnyújtási jog alapján, szolgáltatási kötelezettség terhe mellett biztosítják a szolgáltatásokat. 
1. ábra: A közüzemi szolgáltatások legfontosabb szereplői

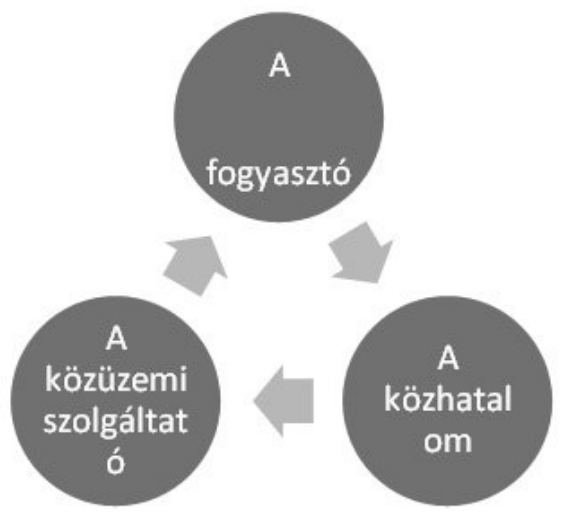

Forrás: saját szerkesztés

- Az állam a szolgáltatók és a fogyasztók közötti jogviszony részletes szabályait ún. közüzemi szabályzatban határozza meg. (Ma már csak a távhőszolgáltatásná!!)

- A közüzemi szolgáltatásokat - jellemzően gazdasági társasági formában szervezik meg és a szolgáltatások korlátozott piaci viszonyok között kerülnek értékesítésre.

- A közszolgáltatás kötelező igénybevétele elrendelhető.

- a fogyasztó, akinek az érdekében (alapvető szükségletei kielégítésére) a szolgáltatás megvalósul,

- a közüzemi szolgáltató, aki korlátozható nyereséggel, ugyanakkor garantált (és csökkent kockázatú) piacon gazdasági tevékenységet 1. táblázat: A megye föbb települési infrastrukturális mutatói

\begin{tabular}{|l|r|r|}
\hline \multirow{2}{*}{ Szolgáltatások } & \multicolumn{2}{|c|}{2007} \\
\cline { 2 - 4 } & $\begin{array}{c}\text { Bekapcsolt települé- } \\
\text { sek száma db }\end{array}$ & $\begin{array}{c}\text { Bekapcsolt lakások } \\
\text { aránya }\end{array}$ \\
\hline Közüzemi vízellátás & 78 & 94,0 \\
\hline Vezetékes gázellátás & 77 & 77,5 \\
\hline Közcsatorna hálózat & 47 & 58,2 \\
\hline Hulladékgyűjtés & 78 & 91,4 \\
\hline
\end{tabular}

Forrás: http://www.jnszm.hu/feltolt/File/tfi/jnszm_infra_2007.pdf

\section{KöZÜZEMI SZOLGÁLTATÁSOK JÁSZ- NAGYKUN-SZOLNOK MEGYÉBEN}

Első körben a lehetséges közüzemi szolgáltatók körét három szektor vizsgálatára szűkítettük:

- a víz- és csatornaszolgáltatás,

- villamos és gázenergia ellátás,

- a kommunális (hulladék) szolgáltatások helyzete.

A vizsgálatot az igénybevevő lakosság szempontjából végezzük, az ellátással kapcsolatos elégedettség a kutatás egyik iránya. A munkát a meglévő és a megyében működő szolgáltatók tényleges összeírásával kezdtük. A szolgáltatókra vonatkozó statisztika adatgyűjtés során a KSH adataira nem támaszkodhatunk, a közüzemi szolgáltatások nem tartoznak egyetlen nemzetgazdasági ágba, így azok egy helyen történő megtalálása nehézségekbe ütközik. Ezért településenként és szektoronként gyűjtöttük össze a szektorban és a térségben működő cégeket. 2013-ban Jász-Nagykun-Szolnok megyében 78 település van. folytat, továbbá

- a közhatalom, amelynek felelősséget kell vállalnia a közüzemi szolgáltatások rendelkezésre állásáért (működőképességéért) és igénybevehetőségéért (megfizethetőségért).
A kutatásban a kiinduláskor felhasznált és rendelkezésre álló szekunder információk egy öt évvel korábbi állapotot mutatnak, a változások rögzítése és megállapítások a kutatás későbbi szakaszában várhatók. 
Máté Zoltán - László Éva - Szakács Attila: A közszolgáltatások marketing tevékenységének...

2. táblázat: A közüzemi ivóvizvezeték- és szennyvizgyüjtö- hálózatba bekapcsolt lakások aránya (2006-)[\%]

\begin{tabular}{|l|r|r|r|r|r|r|r|}
\hline \multicolumn{1}{|c|}{ Megyék } & \multicolumn{1}{c|}{$\mathbf{2 0 0 6}$} & \multicolumn{1}{c|}{$\mathbf{2 0 0 7}$} & \multicolumn{1}{c|}{$\mathbf{2 0 0 8}$} & \multicolumn{1}{c|}{$\mathbf{2 0 0 9}$} & \multicolumn{1}{c|}{$\mathbf{2 0 1 0}$} & \multicolumn{1}{c|}{$\mathbf{2 0 1 1}$} & \multicolumn{1}{c|}{$\mathbf{2 0 1 2}$} \\
\hline Hajdú-Bihar & 53,5 & 62,1 & 64,1 & 64,9 & 64,3 & 66,4 & 68,0 \\
\hline Jász-Nagykun-Szolnok & 52,7 & 58,4 & 62,3 & 63,3 & 65,5 & 66,2 & 68,6 \\
\hline Szabolcs-Szatmár-Bereg & 50,7 & 51,1 & 52,5 & 54,0 & 54,8 & 56,6 & 60,0 \\
\hline Észak-Alföld & $\mathbf{5 2 , 3}$ & $\mathbf{5 7 , 2}$ & $\mathbf{5 9 , 5}$ & $\mathbf{6 0 , 5}$ & $\mathbf{6 1 , 3}$ & $\mathbf{6 2 , 9}$ & $\mathbf{6 5 , 3}$ \\
\hline
\end{tabular}

Forrás: KSH Tájékoztatási adatbázis

\section{Víz-ÉS CSATORNASZOLGÁLTATÁS}

A megye településein a víz és csatornaszolgáltatást általában a városi Önkormányzat által létrehozott vállalkozás nyújtja. Ezek a vállalkozások a város és környéke településeinek nyújtják a szolgáltatást. A megye háztartásainak hálózatba kapcsolása folyamatosan nő és a bekapcsolt háztartások aránya a régió átlaga felett van.

- Kisújszállási Víz- és Csatornamű (Kisújszállás)

- Mezőtúr és Kö. Víz- és Csatornamű (Mezőtúr)

- Jászberényi Vízgazdálkodási Kft. (Jászberény)

- Nagykun Víz- és Csatornamü Kft. (Karcag)

- Tiszamenti Vízmúvek Rt. (Szolnok)

- Törökszentmiklós Térségi Kft. (Törökszentmiklós)

- Víz- és Csatornaművek Rt. Szolnok (Szolnok)

- Túrkevei Vízmű és Városgazdálkodási Kft.

- Tiszamenti Regionális Vízművek Zrt. Kisújszállás

- Kisújszállási Városgazdálkodási Kft.

- Berek -Víz Kft Berekfürdő

\section{Gázszolgáltatás}

A magyar háztartások fütőenergiával való ellátása alapvetően vezetékes gázzal történik. $\mathrm{A}$ megye háztartásainak több mint 70 százalékában van vezetékes gáz. A régióban a Tigáz csoport az általános gázszolgáltató.
A Tigáz Csoport földgázelosztási és gázszolgáltatási tevékenységet végez Magyarország területének egyharmadán. A Tigáz Zrt. földgázt értékesít Magyarország észak- keleti régiójában, megközelítőleg az ország területének egyharmadán. A hajdúszoboszlói székhelyű Tigáz Zrt. méretét tekintve a legjelentősebb magyar gázszolgáltató társaság, amely egyre magasabb színvonalú szolgáltatást nyújt ügyfelei számára, jelentős hatást gyakorolva a gazdaságra és a foglalkoztatottságra egyaránt. Napjainkban több mint 33 ezer km hosszú elosztóhálózaton és csatlakozóvezetéken keresztül végez a társaság gázszolgáltatást, a hazai lakossági és közületi fogyasztók közel 35,4 százalékát ellátva. Tulajdonosai közül legnagyobbak az olasz ENI csoport (50\%) és a német RWE csoport (45\%)

\section{HULLADÉKSZÁLLíTÁs}

A térségben a hulladékgazdálkodást- szállitást, hasznosítást- szintén az önkormányzati vagy kistérségi társulások által létrehozott vállalkozások végzik. A Remondis ZRT a legjelentősebb kommunális szolgáltató cég a megyében.

\section{A KÖZÜZEMI SZOLGÁLTATÁSOK MARKETING TEVÉKENYSÉGÉNEK VIZSGÁLATA}

A fentiekben részletesen ismertetett vállalkozások esetében az utóbbi időben jelentős gazdasági, jogi, és piaci, versenykörnyezeti 
3. táblázat: A rendszeres hulladékgyüjtésbe bevont lakások aránya, \%

\begin{tabular}{|l|r|r|r|r|r|r|r|}
\hline \multicolumn{1}{|c|}{ Megnevezés } & \multicolumn{1}{c|}{2006} & \multicolumn{1}{c|}{2007} & \multicolumn{1}{c|}{2008} & \multicolumn{1}{c|}{2009} & \multicolumn{1}{c|}{2010} & \multicolumn{1}{c|}{2011} & \multicolumn{1}{c|}{2012} \\
\hline Hajdú-Bihar & 90,4 & 91,7 & 92,7 & 90,2 & 89,3 & 87,2 & 86,8 \\
\hline Jász-Nagykun-Szolnok & 88,1 & 89,3 & 89,2 & 88,4 & 87,7 & 85,6 & 84,0 \\
\hline Szabolcs-Szatmár-Bereg & 90,6 & 91,3 & 89,7 & 88,4 & 87,8 & 89,2 & 88,5 \\
\hline Észak-Alföld & $\mathbf{8 9 , 8}$ & $\mathbf{9 0 , 9}$ & $\mathbf{9 0 , 6}$ & $\mathbf{8 9 , 0}$ & $\mathbf{8 8 , 3}$ & $\mathbf{8 7 , 4}$ & $\mathbf{8 6 , 6}$ \\
\hline
\end{tabular}

Forrás: KSH, Tájékoztatási adatbázis

változások következtek be. Megjelentek új adónemek, melyek egy része közvetlenül a fogyasztót terheli, egy részük pedig áttételese kerül a fogyasztók által megfizetésre. Az árképzésben jelennek további olyan kényszerek a közüzemi vállalkozások számára, melyek kényszer pályát jelentenek számukra. Megjelent az állam, tulajdonosi igényekkel egy olyan piacon ahol eddig csak közvetetten volt jelen. Mindezek hatására átstrukturálódni látszik a piac, mind nehézkesebbé válik kivívni a fogyasztók elégedettségét. Mindezen változások ellenére összességében megállapítható, hogy a közüzemi szolgáltatók igyekeznek kommunikálni sajátos helyzetüket, és az ezzel járó változásokat, legyez ez a fogyasztó számára akár pozitív (lásd rezsicsökkentés), akár negatív (lásd beruházások elmaradása). A vevőelégedettség mérése folyamatosan na- pirenden van, azonban a jövedelmezőség csökkenése miatt mind kevesebb erőforrás jut ezek kivívására. A szekunder információk vizsgálata alapján megállapíthatjuk, hogy jelenleg a közüzemi vállalkozások számára leginkább nem a fogyasztói igények mind teljesebb kielégítése, a termékeik fejlesztése, a disztribúciós tevékenységük optimalizálása, valamint a marketing kommunikációs tevékenységük növelése a legfontosabb céljaik, hanem a jelenlegi piaci helyzet értékelése és az ehhez való alkalmazkodás megvalósítása. ÖsSZEGZÉs

A kutatás probléma feltáró és információ gyűjtési fázisában megállapítható, hogy a megye háztartásai a számára közüzemi szolgáltatások rendelkezésre állnak. A számok nem tükrözik azok ellátási színvonalát, ezért ennek vizsgálata további kutatást tesz szükségessé.

Felhasznált irodalom

[1.] Veres Z. Farkas F. Hetesi E. Dinya L.: Nonbusiness marketing és menedzsment, Akadémiai Kiadó, 2004.

[2.] Chikán Attila: Vállalatgazdaságtan, Aula Kiadó Kft 2008

[3.] Ilés Mária. 2000: A közszolgáltató vállalatok gazdasági szabályozása, AULA, Budapest

[4.] Hetesi Erzsébet (2002) A közszolgáltatások marketingje és menedzsmentje JATE Press, Szeged

[5.] Báger Gusztáv és Czakó Erzsébet:A közszféra és a gazdaság versenyképessége 2010

[6.] Dinya L. - Farkas F. - Hetesi E. - Veres Z. (2004) Nonbusiness marketing és menedzsment. KJK-KERSZÖV Jogi és Üzleti Kiadó Kft., Budapest.

[7.] Horváth F. (2002) Közszolgáltatások fogyasztása és finanszírozása. In Hetesi, E. A közszolgáltatások marketingje és menedzsmentje. Szeged. 50-63. o. 
[8.] Illés M. (2000) A közszolgáltató vállalatok gazdasági szabályozása. Aula Kiadó, Budapest.

[9.] Imreh Sz. (2002) Kihívások és válaszok a közszolgálati menedzsmentben. In Hetesi, E. A közszolgáltatások marketingje és menedzsmentje. Szeged. 251-271. o.

[10.] Pukli P. (2002) A közszolgáltatások kutatásának információs háttere. In Hetesi, E. A közszolgáltatások marketingje és menedzsmentje. Szeged. 24-32. 0.

[11.] Révész B. (2002) Marketingkommunikáció a közüzemi szolgáltatóknál. In Hetesi, E. A közszolgáltatások marketingje és menedzsmentje. Szeged. 219-231. o.

[12.] www.ksh.hu

[13.] http://www.jnszm.hu/feltolt/File/tfi/jnszm_infra_2007.pdf 